\title{
Representasi Eksternal Siswa dalam Pemecahan Masalah SPLDV Ditinjau dari Kemampuan Matematika
}

\author{
Rista Ayu Andhani \\ 'Pendidikan matematika, Program Pascasarjana, Univesitas Negeri Surabaya, Indonesia \\ Email: ristaayuandhani2@gmail.com
}

DOI: http://dx.doi.org/10.15294/kreano.v7i2.6615

Rec eived: J uly, 2016; Accepted: September, 2016; Published: December, 2016

\begin{abstract}
Abstrak
Penelitian ini bertujuan untuk mendeskripsikan representasi eksternal siswa yang berkemampuan matematika tinggi, sedang, dan rendah dalam pemecahan masalah SPLDV. Penelitian ini merupakan penelitian kualitatif yang bersifat deskriptif. Penelitian ini dilakukan di SMP Negeri 2 Menganti dengan banyak subjek penelitian 3 siswa perempuan, yaitu seorang siswa berkemampuan matematika tinggi, seorang siswa berkemampuan matematika sedang, dan seorang siswa berkemampuan matematika rendah dengan jenis kelamin sama. Data representasi eksternal siswa diperoleh dari hasil TPM yang dilengkapi dengan hasil wawancara. Hasil penelitian menunjukkan bahwa pada tahap memahami masalah, siswa yang berkemampuan matematika tinggi merepresentasikan secara eksternal informasi yang diketahui dan apa yang ditanya pada permasalahan melalui teks tertulis, sedangkan siswa berkemampuan matematika sedang dan rendah merepresentasikan secara eksternal informasi yang diketahui dan apa yang ditanya pada permasalahan melalui simbol dan teks tertulis. Pada tahap merancang rencana, siswa berkemampuan matematika tinggi, sedang, dan rendah merepresentasikan secara eksternal rencana penyelesaian melalui kata-kata lisan dan membuat model matematika namun siswa berkemampuan matematika rendah tidak dapat membuat model matematika. Pada tahap melaksanakan rencana, siswa berkemampuan matematika tinggi menyatakan secara tertulis tentang penggunaan konsep SPLDV dengan metode substitusi, sedangkan siswa berkemampuan matematika sedang menyatakan penggunaan konsep SPLDV dengan metode eliminasi secara lisan dan siswa berkemampuan matematika rendah menyatakan secara tertulis tentang penggunaan metode eliminasi dan substitusi sedangkan penggunaan konsep SPLDV dinyatakan secara lisan. Selain itu, siswa berkemampuan matematika tinggi, sedang, dan rendah merepresentasikan secara eksternal pelaksanaan rencana dengan memanipulasi model matematika dan menginterpretasi hasil penyelesaian dengan teks tertulis namun siswa berkemampuan matematika rendah tidak dapat memanipulasi model matematika dengan benar. Pada tahap memeriksa kembali, siswa berkemampuan matematika tinggi memeriksa kembali langkah-langkah penyelesaian yang direpresentasikan secara eksternal dengan coretan-coretan pada lembar permasalahan, sedangkan siswa berkemampuan matematika sedang dan rendah merepresentasikannya secara eksternal melalui kata-kata lisan. Selain itu, siswa berkemampuan matematika tinggi, sedang, dan rendah juga membuat kesimpulan yang direpresentasikannya secara eksternal melalui teks tertulis.
\end{abstract}

\begin{abstract}
This research describing external representation of students who have high, middle, and low mathematics ability in SLETV problem solving. This research is a qualitative descriptive research that has been done in SMPN 2 Menganti. Three female students have been selected as subject in this research represent high, middle, and low mathematics ability. Student's external representation data obtain from TPM result including interview result. The result of this research shown that at the stage of understanding the problem, student with high mathematics ability represents externally the information that already known and problem that asked through written text, while students with middle and low mathematics ability represent externally the information that already known and issue that asked through symbols and written text. At the stage of devising the plan, students with high, middle, and low mathematics ability represent externally the finishing plan by speak and make mathematical model but student with low mathematics ability can not create a mathematical model. At the stage of carrying out the plan, student with high mathematics ability stated in writing to use SLETV concept by substitution method, while student with middle mathematics ability stated use of the concept SPLDV with elimination method orally and student with low mathematics ability stated in writing about the use of elimination and substitution methods, while use of the concept SPLDV stated orally. Other than that students with high, middle, and low mathematics ability represent externally the implementation of the plan by manipulating mathematical model and interpret of the problem-solving result by written text but student with low mathematics abi-
\end{abstract}




\section{PENDAHULUAN}

Kartini (2009) menyatakan bahwa pemahaman dibangun oleh siswa sendiri baik secara personal maupun sosial, pemahaman tidak dapat dipindahkan dari guru ke siswa, kecuali melalui keaktifan siswa sendiri untuk menalar dan mengonstruksi sehingga terjadi perubahan konsep menuju ke arah yang lebih kompleks, guru sekedar membantu agar proses kontruksi siswa berjalan dengan baik. Setiap siswa mempunyai cara berbeda untuk mengontruksi pengetahuannya, yaitu dapat mencoba berbagai macam representasi dalam memahami suatu konsep. Representasi sangat diperlukan agar siswa lebih memahami konsep yang dipelajari dan dapat menerapkannya dalam berbagai situasi. Hal tersebut didukung oleh Salkind dan Hjalmarson (2007) yang menyatakan bahwa siswa menggunakan representasi untuk mendukung pemahaman ketika memecahkan masalah matematika atau belajar konsep-konsep matematika.

Hutagaol (2013) menyatakan bahwa "representasi adalah kemampuan siswa mengomunikasikan ide atau gagasan matematika yang dipelajari dengan cara tertentu". Sedangkan Salkind dan Hjalmarson (2007) menyatakan bahwa representasi adalah konfigurasi yang dapat mewakili sesuatu dalam beberapa cara. Representasi yang sering digunakan dalam mengomunikasikan ide-ide matematika adalah diagram, tabel, pernyataan matematika, teks tertulis, ataupun kombinasi dari semuanya.

Representasi dapat dinyatakan secara internal atau eksternal. Representasi internal dari seseorang sulit untuk diamati secara langsung karena merupakan aktivitas mental seseorang dalam pikirannya. Representasi internal seseorang dapat disimpulkan atau diduga berdasarkan representasi eksternalnya. Representasi yang digunakan dalam penelitian ini adalah representasi eksternal karena dapat dilihat dan diukur menggunakan indikator-indikator. Representasi eksternal dapat mempermudah siswa untuk mengubah ide atau gagasan abstrak pada masalah matematika menjadi konsep yang nyata, misalnya dengan gambar, simbol, kata-kata, grafik, tabel, dan lain-lain. Selain itu, representasi eksternal juga diperlukan ketika menerap- kan suatu konsep dalam proses pemecahan masalah matematika. Neria dan Amit (2004) menyatakan bahwa kesuksesan dalam proses pemecahan masalah bergantung pada keterampilan merepresentasikan masalah seperti mengonstruksi dan menggunakan representasi eksternal dalam kata-kata, grafik, tabel, dan persamaan-persamaan serta pemecahan dan manipulasi simbol.

Mustangin (2015) menyatakan suatu masalah yang rumit dan kompleks, bisa menjadi lebih sederhana jika strategi dan pemanfaatan representasi konsep secara eksternal yang digunakan sesuai dengan permasalahan tersebut. Sebaliknya suatu permasalahan akan sulit dipecahkan jika penggunaan representasi eksternalnya tidak tepat. Kesulitan ini akan menjadi semakin kompleks jika siswa tidak bisa merepresentasikan konsep secara eksternal dengan tepat karena keterbatasan alternatif representasi yang dimilikinya. Dengan demikian, representasi eksternal siswa sangat berperan dalam pengambilan keputusan strategi pemecahan masalah yang tepat dan akurat. Menurut Polya (1973), ada empat tahap strategi pemecahan masalah, yaitu memahami masalah (understanding the problem), merancang rencana (devising a plan), melaksanakan rencana (carrying out the plan), dan melihat kembali (looking back).

Berdasarkan pengamatan dan hasil wawancara dengan guru mata pelajaran matematika SMP Negeri 2 Menganti didapatkan bahwa sebagian besar siswa mengalami kesulitan dalam pemecahan masalah SPLDV yang berbentuk soal cerita. Kesulitan tersebut dapat disebabkan oleh kemampuan representasi eksternal siswa. Hutagaol (2013) menyatakan bahwa siswa yang mengerjakan masalah matematika yang berkaitan dengan kemampuan representasi baik representasi internal maupun representasi eksternal, hanya sebagian kecil siswa dapat menjawab dengan benar dan sebagian besar lainnya lemah dalam memanfaatkan kemampuan representasi yang dimilikinya. Hal ini berarti, representasi eksternal sebagian besar siswa yang digunakan dalam pemecahan masalah SPLDV tidak tepat. Salah satu faktor yang mempengaruhi ketidaktepatan representasi eksternal yang digunakan siswa dalam pemecahan masalah 
SPLDV adalah kemampuan yang dimiliki oleh siswa. Hal tersebut didukung oleh Hudiono (2012) yang menyatakan bahwa kemampuan representasi baik representasi internal maupun representasi eksternal menunjukkan kemampuan pemecahan masalah dalam matematika. Kemampuan yang berpengaruh terhadap pemecahan masalah dalam matematika adalah kemampuan matematika.

Kemampuan matematika dapat dibedakan menjadi tiga, yaitu kemampuan rendah, kemampuan sedang, dan kemampuan tinggi. Perbedaan kemampuan matematika memungkinkan terjadinya perbedaan dan keanekaragaman representasi siswa. Menurut Hudiono (2012), representasi siswa baik representasi internal maupun representasi eksternal yang berkemampuan matematika tinggi lebih baik daripada siswa yang berkemampuan matematika sedang, representasi siswa baik representasi internal maupun representasi eksternal yang berkemampuan matematika sedang lebih baik daripada siswa yang berkemampuan matematika rendah. Dalam hal ini, kemampuan matematika siswa ditentukan berdasarkan hasil tes kemampuan matematika.

\section{METODE}

Penelitian ini merupakan penelitian deskriptif kualitatif. Subjek dalam penelitian ini adalah siswa kelas VIII-H SMP Negeri 2 Menganti yang terdiri dari 1 siswa berkemampuan matematika tinggi, 1 siswa berkemampuan matematika sedang, dan 1 siswa berkemampuan matematika rendah. Subjek tersebut dipilih berdasarkan hasil Tes Kemampuan Matematika (TKM).

Terdapat dua jenis instrumen penelitian yaitu: (1) Instrumen utama adalah peneliti sendiri; dan (2) Instrumen pendukung adalah Tes Kemampuan Matematika (TKM), Tugas Pemecahan Masalah SPLDV (TPM), dan pedoman wawancara. Instrumen tersebut digunakan dengan cara pemberian TPM, wawancara, dan triangulasi.

Teknik analisis data dalam penelitian ini yaitu: (1) reduksi data, Reduksi data yaitu kegiatan merangkum, memilih hal-hal yang pokok, memfokuskan pada hal-hal yang penting, mencari tema dan polanya, dan membuang yang tidak perlu sehingga sesuai dengan tujuan penelitian dan data yang telah direduksi akan menjadi lebih sederhana; (2) penyajian data, Setelah data direduksi, langkah selanjutnya adalah menyajikan data. Data akan diorganisasikan dan dikategorikan sehingga mempermudah dan memungkinkan peneliti untuk menarik kesimpulan dari data tersebut. Penyajian data yang sering digunakan dalam penelitian kualitatif adalah teks bersifat naratif; dan (3) penarikan kesimpulan, Penarikan kesimpulan berdasarkan hasil analisis terhadap data yang telah terkumpul, baik data hasil TPM maupun data hasil wawancara. Kesimpulan yang diambil merupakan kesimpulan tentang representasi eksternal siswa dalam pemecahan masalah SPLDV ditinjau dari kemampuan matematika

\section{HASIL DAN PEMBAHASAN}

Daftar subjek penelitian berdasarkan hasil TKM ini tersaji pada Tabel 1.

Tabel 1 Daftar Subjek Penelitian Berdasarkan Hasil TKM

\begin{tabular}{cccccc}
\hline No & $\begin{array}{c}\text { Inisial } \\
\text { Nama }\end{array}$ & $\begin{array}{c}\text { Gen- } \\
\text { der }\end{array}$ & $\begin{array}{c}\text { Ni- } \\
\text { lai }\end{array}$ & $\begin{array}{c}\text { Kat- } \\
\text { egori }\end{array}$ & Kode \\
\hline 1 & NRT & P & 100 & Tinggi & SKMT \\
2 & KEF & P & 74 & Sedang & SKMS \\
3 & LLK & P & 24 & Rendah & SKMR \\
\hline
\end{tabular}

\section{HASIL PENELITIAN}

Representasi Eksternal Siswa Berkemampuan Matematika Tinggi (SKMT) dalam Pemecahan Masalah SPLDV

Pada tahap memahami masalah, SKMT menyajikan kembali informasi yang diketahui dan apa yang ditanyakan dalam bentuk teks tertulis. Setelah menyajikan kembali informasi yang diketahui dan apa yang ditanyakan, SKMT mengungkapkan langkah-langkah penyelesaian secara lisan, yaitu menentukan nilai variabel dengan metode substitusi dan mensubstitusikan nilai variabel yang diperoleh ke model matematika yang ditanyakan untuk menjawab pertanyaan pada permasalahan serta membuat model matematika dari 
apa yang diketahui pada tahap merancang rencana. Kemudian pada tahap melaksanakan rencana, SKMT menyatakan secara tertulis bahwa penyelesaian masalah menggunakan metode substitusi dalam konsep SPLDV dan melakukan langkah-langkah penyelesaian sesuai dengan rencana yang telah diungkapkan sebelumnya, yaitu memanipulasi model matematika dengan metode substitusi untuk menentukan nilai variabel kemudian mensubstitusikannya ke model matematika yang ditanyakan dan juga menuliskan keterangan berupa teks tertulis terhadap nilai variabel yang diperoleh. Pada tahap terakhir, yaitu tahap memeriksa kembali, SKMT melakukan pemeriksaan kembali dengan membuktikan kebenaran model matematika yang diketahui dengan mensubstitusikan nilai variabel yang diperoleh dan menuliskan kesimpulan berupa teks tertulis.

Representasi Eksternal Siswa Berkemampuan Matematika Sedang (SKMS) dalam Pemecahan Masalah SPLDV

Pada tahap memahami masalah, SKMS menyajikan kembali informasi yang diketahui dengan menetapkan variabel kemudian membuat model matematika sedangkan menyajikan apa yang ditanyakan dalam bentuk teks tertulis. Kemudian pada tahap merancang rencana, SKMS mengungkapkan langkah-langkah penyelesaian secara lisan, yaitu menentukan nilai variabel dengan metode eliminasi dan menggunakan operasi perkalian dan pernjumlahan untuk menjawab pertanyaan pada permasalahan serta membuat model matematika dari apa yang diketahui. Pada tahap selanjutnya, yaitu tahap melaksanakan rencana, SKMS mengungkapkan penggunaan metode eliminasi dalam konsep SPLDV untuk menyelesaikan permasalahan tidak secara tertulis melainkan secara lisan dan juga melakukan langkah-langkah penyelesaian sesuai dengan rencana yang telah dibuat, yaitu memanipulasi model matematika dengan metode eliminasi untuk menentukan nilai variabel dan menentukan hasil akhir menggunakan operasi perkalian dan penjumlahan namun pada pertanyaan pertama terjadi kesalahan dalam merepresentasikan secara eksternal sehingga jawaban yang diperoleh salah serta menuliskan keterangan berupa teks tertulis terhadap nilai variabel yang diperoleh. Dan pada tahap terakhir, yaitu tahap memeriksa kembali, SKMS melakukan pemeriksaan kembali dengan membaca langkah-langkah penyelesaian dan memeriksa coretan-coretan perhitungan pada lembar jawaban, lembar permasalahan, atau kertas buram serta menuliskan kesimpulan berupa teks tertulis

\section{Representasi Eksternal Siswa Berkemam- puan Matematika Rendah (SKMR) dalam Pemecahan Masalah SPLDV}

Pada tahap memahami masalah, SKMR menyajikan kembali informasi yang diketahui dengan menetapkan variabel kemudian membuat model matematika pada kalimat pertama dan untuk kalimat kedua dalam bentuk teks tertulis sedangkan menyajikan apa yang ditanyakan dalam bentuk teks tertulis. Setelah menyajikan kembali informasi yang diketahui dan apa yang ditanyakan, SKMR mengungkapkan langkah-langkah penyelesaian secara lisan, yaitu menentukan nilai variabel dengan metode eliminasi dan substitusi kemudian mensubstitusikan nilai variabel yang diperoleh ke model matematika yang ditanyakan untuk menjawab pertanyaan pada permasalahan namun pada tahap ini, SKMR tidak dapat membuat model matematika dari apa yang diketahui dengan benar. Pada tahap melaksanakan rencana, SKMR mengungkapkan dalam bentuk teks tertulis hanya pada penggunaan metode eliminasi dan substitusi sedangkan konsep SPLDV yang digunakan untuk menyelesaikan permasalahan diungkapkan dengan kata-kata lisan. Selain itu, SKMR juga melakukan langkah-langkah penyelesaian sesuai dengan rencana yang telah dibuat namun SKMR tidak dapat memanipulasi model matematika dengan benar sehingga nilai variabel yang diperoleh dengan metode campuran salah kemudian untuk menjawab pertanyaan pada permasalahan, SKMR melakukan substitusi nilai variabel yang diperoleh ke model matematika yang ditanyakan dan mengungkapkan keterangan berupa kata-kata lisan terhadap nilai variabel yang diperoleh. Pada tahap terakhir, yaitu tahap memeriksa 
kembali, SKMR melakukan pemeriksaan kembali dengan membaca langkah-langkah penyelesaian dan memeriksa coretan-coretan perhitungan pada kertas buram serta menuliskan kesimpulan berupa teks tertulis.

\section{PEMBAHASAN}

Representasi Eksternal Siswa Berkemampuan Matematika Tinggi (SKMT) dalam Pemecahan Masalah SPLDV

Pada tahap memahami masalah, SKMT menyajikan kembali informasi yang diketahui dan apa yang ditanyakan dalam bentuk teks tertulis. Pada tahap merancang rencana, SKMT mengungkapkan rencana penyelesaian secara lisan, yaitu menentukan nilai variabel dengan metode substitusi kemudian menjawab pertanyaan pada permasalahan dengan mensubstitusikan nilai variabel yang telah diperoleh. Selain itu, pada tahap ini SKMT juga membuat model matematika berdasarkan apa yang diketahui pada permasalahan untuk mempermudah melaksanakan rencana penyelesaian yang telah dibuat.

Pada tahap melaksanakan rencana, SKMT menuliskan bahwa penyelesaian permasalahan menggunakan konsep SPLDV dengan metode substitusi dan memecahkan permasalahan sesuai dengan rencana penyelesaian yang telah dibuat, yaitu melakukan manipulasi model matematika dengan menggunakan metode substitusi untuk menentukan nilai variabel kemudian mensubstitusikannya ke model matematika yang ditanyakan untuk menjawab pertanyaan permasalahan. Selain itu, SKMT menuliskan kesimpulan berupa kalimat di akhir jawaban dan juga menuliskan keterangan nilai variabel yang diperoleh dengan kata-kata. Pada tahap memeriksa kembali, SKMT melakukan pemeriksaan kembali dengan mensubstitusikan nilai variabel yang telah diperoleh ke model matematika yang diketahui untuk membuktikan kebenarannya dan juga menuliskan kesimpulan berupa kalimat untuk memperjelas jawaban tentang apa yang ditanyakan pada permasalahan.

Berdasarkan pemaparan di atas, SKMT tidak mengalami kesulitan dalam pemecahan masalah SPLDV. Sesuai dengan pendapat $\mathrm{Ne}-$ ria dan Amit (2004) yang menyatakan bahwa kesuksesan dalam proses pemecahan masalah bergantung pada keterampilan merepresentasikan masalah seperti mengonstruksi dan menggunakan representasi eksternal dalam kata-kata, grafik, tabel, dan persamaanpersamaan serta pemecahan dan manipulasi simbol.

Representasi Eksternal Siswa Berkemampuan Matematika Sedang (SKMS) dalam Pemecahan Masalah SPLDV

Pada tahap memahami masalah, SKMS menyajikan kembali informasi yang diketahui pada permasalahan dalam bentuk simbol, yaitu menetapkan variabel kemudian membuat model matematika dan menyajikan kembali informasi yang ditanya pada permasalahan dalam bentuk kalimat/teks tertulis. Pada tahap merancang rencana, SKMS mengungkapkan rencana penyelesaian secara lisan, yaitu menentukan nilai variabel dengan metode eliminasi dan menjawab pertanyaan dengan menggunakan operasi perkalian dan penjumlahan. Pada tahap ini, SKMS membuat model matematika pada tahap sebelumnya, yaitu tahap memahami masalah berdasarkan apa yang diketahui di permasalahan sehingga mempermudah pelaksanaan rencana yang telah dibuat.

Pada tahap melaksanakan rencana, SKMS tidak mengungkapkan secara tertulis melainkan secara lisan tentang penggunaan metode eliminasi dalam konsep SPLDV untuk menyelesaikan masalah SPLDV. Selain itu, SKMS melakukan manipulasi model matematika dengan benar melalui metode eliminasi untuk menentukan nilai variabel kemudian menjawab pertanyaan dengan menggunakan operasi perkalian dan penjumlahan namun terdapat kesalahan dalam merepresentasikan secara eksternal apa yang ditanya pada permasalahan sehingga mengakibatkan penyelesaian untuk pertanyaan pertama salah. Kesalahan SKMS dalam merepresentasikan secara eksternal disebabkan oleh ketidakpahaman SKMS mengenai apa yang ditanyakan pada permasalahan. Sesuai dengan pendapat Montague (2004) yang menyatakan bahwa 
representasi terhadap masalah adalah dasar untuk memahami masalah dan membuat suatu rencana untuk memecahkan masalah sehingga siswa yang mengalami kesulitan dalam melakukan representasi eksternal akan memiliki kesulitan dalam memecahkan masalah tersebut. SKMS juga menuliskan kesimpulan berupa kalimat dan juga menuliskan keterangan nilai variabel yang telah diperoleh dalam bentuk kata-kata.

Pada tahap memeriksa kembali, SKMS melakukan pemeriksaan kembali dengan membaca kembali langkah-langkah penyelesaian dari atas sampai bawah dan memeriksa kembali coretan-coretan perhitungannya. Hal tersebut diungkapkan secara lisan oleh SKMS. Selain itu, SKMS juga menuliskan kesimpulan berupa kalimat.

\section{Representasi Eksternal Siswa Berkemam- puan Matematika Sedang (SKMS) dalam Pemecahan Masalah SPLDV}

Pada tahap memahami masalah, SKMR menyajikan informasi pertama yang diketahui dalam bentuk simbol, yaitu menetapkan variabel kemudian membuat model matematika, sedangkan untuk informasi kedua, SKMR menyajikannya dalam bentuk teks. Selain itu, SKMR menyajikan kembali informasi yang ditanya pada permasalahan dalam bentuk teks tertulis. Pada tahap merancang rencana, SKMR mengungkapkan secara lisan mengenai rencana penyelesaian, yaitu menentukan nilai variabel yang pertama dengan metode eliminasi dan variabel kedua dengan metode substitusi kemudian menjawab pertanyaan dengan mensubstitusikan nilai variabel yang diperoleh ke model matematika yang ditanyakan. Pada tahap ini, SKMR tidak dapat membuat model matematika dengan benar karena ketidakpahaman terhadap informasi yang diketahui dan kemampuan representasi eksternal SKMR masih rendah sehingga tidak dapat merepresentasikan secara eskternal apa yang diketahui ke dalam bentuk model matematika. Hal tersebut sesuai dengan pendapat Mandur, Sadra, dan Supatra (2013) yang menyatakan bahwa tinggi rendahnya kemampuan matematika siswa ditentukan oleh kemampuan representasi eksternal siswa. Dengan kata lain bahwa siswa yang memiliki kemampuan matematika rendah maka kemampuan representasi eksternalnya juga rendah. SKMR juga membuat model matematika dengan membuat pemisalan terlebih dahulu berdasarkan unsur-unsur yang diketahui pada permasalahan dengan menggunakan variabel yang telah ditetapkan.

Pada tahap melaksanakan rencana, SKMR mengungkapkan dalam bentuk teks tertulis hanya pada penggunaan metode eliminasi dan substitusi sedangkan konsep SPLDV untuk menyelesaikan masalah diungkapkan secara lisan. Pada tahap ini, SKMR menyelesaikan masalah sesuai dengan rencana penyelesaian yang telah dibuat namun SKMR tidak dapat memanipulasi model matematika dengan benar disebabkan kesalahan dalam menggunakan operasi bilangan. Hal tersebut terjadi disebabkan kekurangpahaman SKMR terhadap konsep SPLDV dengan menggunakan metode eliminasi untuk menyelesaikan masalah dan tidak dapat melakukan operasi pengurangan. Sesuai dengan pendapat Dettori dan Lemut (1995) yang menyatakan bahwa representasi eksternal terlibat dalam proses pemecahan masalah SPLDV, yaitu saat memahami masalah, menyusun strategi pemecahan masalah, dan melakukan perhitungan sehingga siswa yang mengalami kesulitan dalam melakukan representasi eksternal akan memiliki kesulitan juga dalam menyelesaikan masalah dengan benar. Kemudian untuk menjawab pertanyaan pada permasalahan, SKMR mensubstitusikan nilai variabel ke model matematika yang ditanyakan. SKMR juga menuliskan kesimpulan berupa kalimat di akhir jawaban dan mengungkapkan secara lisan mengenai keterangan nilai variabel yang telah diperoleh.

Pada tahap memeriksa kembali, SKMR mengungkapkan secara lisan bahwa SKMR melakukan pemeriksaan kembali dengan membaca langkah-langkah penyelesaian dari awal sampai akhir dan memeriksa kembali coretan-coretan perhitungannya. Selain itu, SKMR juga menuliskan kesimpulan berupa kalimat pada akhir jawaban tiap nomor. 


\section{PENUTUP}

\section{Simpulan}

Deskripsi Representasi Eksternal Siswa

Berkemampuan Matematika Tinggi (SKMT) dalam Pemecahan Masalah SPLDV

Siswa merepresentasikan secara eksternal informasi yang diketahui dan ditanya pada permasalahan melalui teks tertulis pada tahap memahami masalah. Selanjutnya pada tahap merancang rencana, siswa merepresentasikan secara eksternal rencana penyelesaian melalui kata-kata lisan, yaitu menentukan nilai variabel dengan metode substitusi dan menentukan hasil akhir dengan mensubstitusikan nilai variabel yang telah diperoleh ke model matematika yang ditanyakan. Selain itu, siswa juga membuat model matematika untuk melaksanakan rencana penyelesaian yang telah dibuat. Pada tahap melaksanakan rencana, siswa menuliskan penyelesaian permasalahan menggunakan metode substitusi dalam konsep SPLDV kemudian merepresentasikan secara eksternal mengenai pelaksanaan rencana melalui teks tertulis, yaitu dengan memanipulasi model matematika dan menginterpretasikan hasil jawaban dengan teks tertulis. Pada tahap memeriksa kembali, siswa memeriksa kembali langkah-langkah penyelesaian yang direpresentasikan secara eksternal dengan mensubstitusikan nilai variabel yang diperoleh ke model matematika yang telah dibuat. Selain itu, siswa juga membuat kesimpulan yang direpresentasikan secara eksternal melalui teks tertulis.

Deskripsi Representasi Eksternal Siswa Berkemampuan Matematika Sedang (SKMS) dalam Pemecahan Masalah SPLDV

Siswa merepresentasikan secara eksternal informasi yang diketahui dan ditanya pada permasalahan melalui simbol dan teks tertulis pada tahap memahami masalah. Pada tahap merancang rencana, siswa merepresentasikan secara eksternal rencana penyelesaian melalui kata-kata lisan, yaitu menentukan nilai variabel dengan metode eliminasi dan menentukan hasil akhir dengan menggunakan operasi perkalian dan penjumlahan. Selain itu, pada tahap ini subjek juga membuat mo- del matematika. Pada tahap melaksanakan rencana, siswa tidak merepresentasikan secara eksternal dengan teks tertulis melainkan dengan kata-kata lisan mengenai penyelesaian permasalahan menggunakan metode eliminasi dalam konsep SPLDV. Selain itu, siswa merepresentasikan secara eksternal tentang pelaksanaan rencana melalui teks tertulis dengan memanipulasi model matematika dan menginterpretasikan hasil jawaban melalui teks tertulis. Untuk menjawab pertanyaan pertama, siswa tidak dapat merepresentasikan secara eksternal dengan benar mengenai apa yang ditanyakan pada permasalahan. Pada tahap memeriksa kembali, siswa merepresentasikan secara eksternal melalui kata-kata lisan bahwa siswa memeriksa kembali langkah-langkah penyelesaian dengan membacanya dari awal sampai akhir dan memeriksa perhitungan setiap langkah. Selain itu, siswa juga membuat kesimpulan yang direpresentasikan secara eksternal melalui teks tertulis.

\section{Deskripsi Representasi Eksternal Siswa \\ Berkemampuan Matematika Sedang (SKMS) dalam Pemecahan Masalah SPLDV}

Siswa merepresentasikan secara eksternal informasi yang diketahui pada permasalahan melalui simbol dan teks tertulis sedangkan representasi eksternal informasi yang ditanya melalui teks tertulis pada tahap memahami masalah. Selanjutnya pada tahap merancang rencana, siswa merepresentasikan secara eksternal rencana penyelesaian melalui kata-kata lisan, yaitu menentukan nilai variabel dengan metode eliminasi dan substitusi dan menentukan hasil akhir dengan mensubstitusikan nilai variabel yang diperoleh ke model matematika yang ditanyakan. Selain itu, pada tahap ini siswa tidak dapat membuat model matematika dengan benar. Pada tahap melaksanakan rencana, siswa merepresentasikan secara eksternal dalam bentuk teks tertulis hanya pada penggunaan metode eliminasi dan substitusi sedangkan penggunaan konsep SPLDV untuk menyelesaikan masalah direpresentasikan secara eksternal melalui kata-kata lisan. Siswa juga merepresentasikan secara eksternal mengenai pelaksanaan rencana dalam bentuk 
teks tertulis tetapi siswa tidak dapat memanipulasi model matematika dengan benar dan pada tahap ini, siswa juga menginterpretasikan hasil jawaban dengan kata-kata lisan. Pada tahap memeriksa kembali, siswa merepresentasikan secara eksternal melalui katakata lisan bahwa siswa memeriksa kembali langkah-langkah penyelesaian pada lembar jawaban dengan membacanya dari awal sampai akhir dan memeriksa perhitungan setiap langkah. Selain itu, siswa juga membuat kesimpulan yang direpresentasikan secara eksternal melalui teks tertulis.

\section{Saran}

Berdasarkan simpulan penelitian di atas, peneliti mengemukakan saran, yaitu guru mata pelajaran matematika diharapkan dapat merancang strategi pembelajaran yang tepat dalam pengajaran SPLDV sehingga siswa berkemampuan matematika tinggi, sedang, dan rendah memiliki kemampuan representasi eksternal yang baik dan guru juga diharapkan melakukan evaluasi terhadap proses dan cara siswa merepresentasikan secara eksternal dalam memecahkan suatu masalah beserta pemberian scaffoldingnya sehingga siswa dapat memecahkan masalah dengan baik dan benar terutama pada siswa berkemampuan matematika sedang dan rendah.

\section{DAFTAR PUSTAKA}

Dettori, G., \& Lemut, E. (1995). External representations in arithmetic problem solving. In Exploiting mental imagery with computers in mathematics education, 138, pp. 20-33. Springer Berlin Heidelberg.

Hudiono, B. (2012). Peran Pembelajaran Diskursus Multi Representasi terhadap Pengembangan Kemampuan Matematika dan Daya Representasi pada Siswa SLTP. Jurnal Cakrawala Kependidikan, 8(2), 85-99.

Hutagaol, K. (2013). Pembelajaran Kontekstual Untuk Meningkatkan Kemampuan Representasi Matematis Siswa Sekolah Menengah Pertama. Infinity Journal, 2(1), 85-99.

Kartini, K. (2009). Peranan Representasi Dalam Pembelajaran Matematika. In Seminar Nasional Matematika dan Pendidikan Matematika 2009. Jurusan Pendidikan Matematika FMIPA UNY.

Mandur, K.; Sadra, I.W.; dan Suparta, I.N. (2001). Kontribusi Kemampuan Koneksi, Kemampuan Representasi, dan Disposisi Matematis terhadap Prestasi Belajar Matematika Siswa SMA Swasta di Kabupaten Manggarai. Jurnal Pendidikan Matematika, 2.

Montague, M. (2004). Math problem solving for middle school students with disabilities. Recuperado $e l, 18$.

Mustangin. (2015). Representasi Konsep dan Peranannya dalam Pembelajaran Matematika di Sekolah. Jurnal Pendidikan Matematika. 1(1), 15-21.

Neria, D., \& Amit, M. (2004). Students preference of non-algebraic representations in mathematical communication'. In Proceedings of the 28th Conference of the International Group for the Psychology of Mathematics Education (Vol. 3, pp. 409-416).

Polya, G. (1973). How to Solve It: A New Aspect of Mathematical Method. Second Edition. New Jersey: Princeton University Press.

Salkind, G. M. \& Hjalmarson, M. (2007). Mathematical Representations. http://mason.gmu.edu/gsalkind/portofolio/products/857litreview.pdf. Diunduh pada tanggal 25 November 2015. 